\title{
Praktik Penghindaran Pajak Sebelum dan Setelah Pandemi Covid - 19 di Indonesia
}

Fa'iq Mirza Barid ${ }^{1}$, Sartika Wulandari²

DOI: https://doi.org/10.35838/jrap.2021.008.02.17

${ }^{1}$ Universitas Stikubank, Jawa Tengah, Semarang

${ }^{2}$ Universitas Stikubank, Jawa Tengah, Semarang

\author{
ARTICLE INFO \\ JEL Classification: \\ H26; O16
}

Key words:

tax avoidance, covid-19

\begin{abstract}
Weak economic conditions during the Covid-19 pandemic resulted in a decline in tax revenue in Indonesia. The government seeks to increase economic activity by providing tax incentive programs to taxpayers affected by the Covid-19 pandemic. However, the company considers the program as one of the loopholes to practice tax avoidance. This study aims to look at the differences in tax avoidance practices before and during the Covid-19 pandemic. The type of data used is quantitative data derived from the annual financial statements. The population in this study are manufacturing companies listed on the Indonesia Stock Exchange (IDX) for the 2019-2020 period. The sample of this research was taken based on purposive sampling using certain criteria so as to get 78 samples from 39 manufacturing companies. The method used in this study is paired samples $t$-test analysis using the IBM SPSS Statistics 24 tool. Based on the results of this study, it shows that there is an increase in tax avoidance practices during the Covid-19 pandemi. This resulted in a decrease in state tax revenues during 2020.
\end{abstract}

\begin{abstract}
ABSTRAK
Lemahnya kondisi ekonomi dimasa pandemi Covid-19 mengakibatkan turunnya penerimaan pajak di Indonesia. Pemerintah berupaya untuk meningkatkan kegiatan ekonomi dengan cara memberikan program insentif perpajakan kepada wajib pajak yang terkena dampak pandemi Covid-19. Namun perusahaan menganggap program tersebut sebagai salah satu celah untuk melakukan praktik penghindaran pajak. Penelitian ini bertujuan untuk melihat perbedaan praktik penghindaran pajak sebelum dan saat pandemi Covid-19. Jenis data yang digunakan adalah data kuantitatif yang berasal dari laporan keuangan tahunan. Populasi dalam penelitian ini yaitu perusahaan manufaktur yang terdaftar di Bursa Efek Indonesia (BEI) periode 2019-2020. Sampel penelitian ini diambil berdasarkan purposive sampling dengan menggunakan beberapa kriteria tertentu sehingga mendapatkan 78 sampel dari 39 perusahaan manufaktur. Metode yang digunakan dalam penelitian ini yaitu analisis paired samples $t$ test dengan menggunakan alat bantu IBM SPSS Statistics 24. Berdasarkan hasil penelitian ini menunjukkan bahwa terjadi peningkatan praktik penghindaran pajak pada saat pandemi Covid-19. Sehingga mengakibatkan penerimaan pajak Negara selama tahun 2020 mengalami penurunan.
\end{abstract}

\section{PENDAHULUAN}

Lebih dari satu tahun Indonesia dilanda pandemi Covid-19. Covid-19 (Coronavirus disease 2019) merupakan jenis penyakit yang disebabkan oleh salah satu varian coronavirus baru yaitu severe acute respiratory syndrome coronavirus 2 (SARS-CoV-2) (Temsah et al., 2020). Virus SARS-CoV-2 telah membunuh lebih dari 512.000 dan mengganggu mata pencaharian miliaran orang (Marteleto, Guedes, Coutinho, \& Weitzman, 2020).
Pandemi Covid-19 yang sedang berlangsung membawa dampak yang luar biasa (Laffitte, Martin, Parenti, Souilard, \& Farid, 2020). Dengan adanya pandemi Covid-19 ini menyebabkan krisis kesehatan, selain itu juga memicu terjadinya krisis ekonomi (Asmara, 2020). Pemerintah juga melakukan upaya untuk meningkatkan ekonomi Negara tidak semakin terpuruk (Nidya, 2020). Salah satu upaya yang dilakukan pemerintah yaitu dengan meningkatkan kegiatan ekonomi 
berupa program insentif perpajakan kepada pelaku usaha (Kementrian Keuangan RI, 2020b).

Pemberian insentif pajak ini diatur pada Peraturan Menteri Keuangan (PMK) Nomor 86/PMK.03/2020 tentang insentif pajak untuk wajib pajak terdampak pandemi corona virus disease 2019 bahwa insentif pajak penghasilan (PPh) final ditanggung pemerintah (DTP) untuk wajib pajak terdampak pandemi Covid19(Kementrian Keuangan RI, 2020a).

Upaya yang dilakukan pemerintah merupakan bagian dari Pemulihan Ekonomi Nasional (PEN) ini terdiri dari penurunan tariff PPh Badan sesuai dengan Pasal 5 ayat (1) Perppu nomor 1 Tahun 2020 dan Insentif perpajakan seperti pembebasan PPh 22 impor dan pengurangan angsuran $\mathrm{PPh} 25$ sesuai dengan PMK 23 Tahun 2020 sebagaimana telah beberapa kali diubah terakhir dengan PMK 110 Tahun 2020 (Firmansyah \& Ardiansyah, 2020). Selain itu pemberian insentif pajak dapat berupa pembebasan pajak, penurunan tarif pajak, pengurangan beban pajak dan relaksasi pelayanan pajak (Suhaidar, Rosalina, \& Pratiwi, 2020). Dengan adanya insentif ini direspon baik oleh perusahaan, sesuai dengan paparan Menteri Keuangan tanggal 25 November 2020 yang menyatakan bahwa lebih dari 451.026 perusahaan sudah mengajukan permohonan insentif pajak dan sebanyak 214.097 permohonan telah disetujui oleh Kementrian Keuangan (Nordiansyah, 2020).

Pajak merupakan kontribusi yang diberikan oleh wajib pajak kepada Negara tanpa mendapatkan timbal balik untuk kemakmuran rakyat yang bersifat memaksa dan mengumpulkan berdasarkan hukum (Irianto \& S.Ak, 2017). Penerimaan pajak digunakan untuk pembiayaan di tingkat pusat maupun daerah, sehingga penerimaan pajak harus bisa mencapai tingkat yang maksimal (Adisamartha \& Noviari, 2015). Pemerintah belum mampu merealisasikan penerimaan pajak secara maksimal hingga saat ini. Data penerimaan pajak tahun 2020 menurut Tax Justice Network mencatat sebesar Rp. 69,1 triliun yang tidak dapat dipungut akibat praktik penghindaran pajak di Indonesia. Nominal tersebut setara dengan 4,39\% dari total penerimaan pajak Indonesia (Wildan, 2020). Berdasarkan data penerimaan pajak tersebut memungkinkan pihak manajer melakukan praktik penghindaran pajak dengan cara memanfaatkan celah dari regulasi pajak baru dan insentif pajak.

Penyebab utama yang dianggap sebagai salah satu faktor yang menyebabkan tidak tercapainya penerimaan pajak adalah aktivitas penghindaran pajak (Septiawan, Ahmar, \& Darminto, 2021). Jutaan pembayar pajak menggunakan beberapa bentuk penghindaran pajak (Sunarto, Widjaja, \& Oktaviani, 2021). Hanlon \& Heitzman, (2010) menyatakan bahwa penghindaran pajak merupakan salah satu kebijakan manajemen dalam perencanaan pajak.

Perusahaan melakukan manajemen pajak dalam upaya meminimalkan pembayaran pajak. Manajemen pajak merupakan salah satu sarana untuk memenuhi kewajiban perpajakan dengan benar, namun jumlah pajak yang dibayar perusahaan dapat ditekan serendah mungkin (Khoirul Nisa \& Wulandari, 2021). Menurut pihak internal perusahaan, pajak dianggap sebagai beban dan dapat mengurangi laba yang cukup signifikan. Ada perbedaan tujuan dari pemerintah yang menginginkan penerimaan pajak yang lebih besar dan sangat bertolak belakang dengan tujuan dari perusahaan yang menginginkan untuk membayar pajak seminimal mungkin. Sehingga perusahaan diwajibkan untuk membayarkan pajaknya secara berkala sesuai dengan peraturan perundang-undangan yang berlaku. Hal tersebut yang membuat perusahaan melakukan berbagai cara agar dapat mengurangi jumlah pajak atau meminimalkan beban pajak yang dibayarkan. Cara yang dapat digunakan oleh perusahaan yaitu dengan cara menggunakan pengecualian, dan diperbolehkan pemotongan dalam persyaratan, serta memanfaatkan celah dalam undang-undang pajak yang berlaku (Pattiasina, Tammubua, Numberi, Patiran, \& Temalagi, 2019).

Penelitian ini dilakukan pada perusahaan 
manufaktur yang terdaftar di Bursa Efek Indonesia (BEI) pada tahun 2019 dan 2020. Perusahaan manufaktur dipilih karena memiliki kontribusi terbesar terhadap pertumbuhan ekonomi Indonesia melalui pajak. Tujuan dari penelitian ini untuk membuktikan dan membandingkan perusahaan dalam melakukan praktik penghindaran pajak di masa sebelum dan saat pandemi Covid-19.

\section{TELAAH TEORI PENGEMBANGAN HIPOTESIS} Agency Theory

Teori agensi menjelaskan tentang hubungan antara pemilik kepentingan (principle) dengan manajer (agent) dalam mengelola perusahaan (Jensen \& Meckling, 1976). Manajer menggunakan strategi perusahaan yang kompleks (Chen, $\mathrm{Xu}$, \& Jebran, 2021). Kondisi tersebut berarti bahwa agen sebagai pengelola perusahaan dapat bertindak untuk memenuhi kepentingan pribadinya. Hal ini berlawanan dengan kepentingan principal yang berusaha untuk memaksimalkan pengembalian atas sumber dayanya, sehingga hubungan ini memicu adanya perbedaan kepentingan antara pemilik perusahaan dengan manager yang menyebabkan ketidakefisien informasi yang diperoleh keduanya. Perbedaan kepentingan antara principle dan agent dapat mempengaruhi berbagai hal yang berkaitan dengan kinerja perusahaan, salah satunya adalah kebijakan perusahaan mengenai pajak perusahaan. Agent diberikan otoritas dan kewenangan pengambilan keputusan oleh principle untuk menjalankan perusahaan.

\section{Penghindaran Pajak}

Penghindaran pajak adalah upaya yang dilakukan secara legal dan aman bagi wajib pajak karena itu tidak bertentangan dengan ketentuan perpajakan, dimana metode dan teknik yang digunakan cenderung memanfaatkan kelemahan yang terdapat dalam undang-undang dan peraturan perpajakan itu sendiri, untuk memperkecil jumlah pajak yang terutang (Anggraeni \&
Oktaviani, 2021). Selama masa pandemi ini, terjadi perbedaan kondisi perekonomian. Perbedaan tersebut mempengaruhi pembayaran pajak karena adanya penurunan laba yang dihasilkan oleh perusahaan. Oleh karena itu pemerintah menerapkan relaksasi pajak berupa insentif pajak dengan cara peralihan pembayaran pajak selama 6 bulan mulai dari bulan April-September 2020 yang dibebankan kepada pemerintah (PDP). Namun dengan adanya insentif pajak yang diberikan oleh pemerintah tersebut, dianggap sebagai celah oleh perusahaan untuk melakukan praktik penghindaran pajak guna mempertahankan kondisi ekonomi perusahaan dan nilai perusahaan. Hal ini sejalan dengan penelitian yang dilakukan oleh (Suhaidar et al., 2020) yang menyatakan bahwa terjadi peningkatan penghindaran pajak pada saat pandemi Covid-19, sehingga hipotesis pada penelitian ini dapat dirumuskan:

$\mathrm{H}_{1}$ : Terdapat perbedaan praktik penghindaran pajak sebelum pandemi Covid-19 dan saat pandemi Covid-19

\section{METODE PENELITIAN}

Penelitian ini menggunakan pendekatan kuantitatif dengan menggunakan data sekunder, yang berupa laporan keuangan atau annual report. Populasi dalam penelitian ini adalah perusahaan manufaktur yang terdaftar di Bursa Efek Indonesia (BEI) periode 2019 dan 2020. Sumber data laporan keuangan tersebut diperoleh melalui website www.idx.co.id. Teknik pemilihan sampel menggunakan metode non-probability sampling yaitu teknik purposive sampling yang bertujuan untuk mendapatkan sampel yang sesuai dengan kriteria dan tujuan yang diinginkan oleh peneliti. Kriteria untuk pengambilan sampel ini yaitu: (1) Perusahaan manufaktur yang terdaftar di BEI periode 2019-2020, (2) Perusahaan manufaktur yang menyajikan laporan keuangan atau annual report selama periode 2019-2020, (3) Laporan keuangan atau annual report yang disajikan dalam Rupiah, (4) Perusahaan manufaktur yang tidak mengalami kerugian selama periode 2019- 
2020, (5) Perusahaan manufaktur yang membayar pajak tidak sesuai dengan peraturan perundang-undangan.

Berdasarkan teknik sampling tersebut diperoleh sebanyak 39 perusahaan manufaktur, dengan sampel penelitian sebanyak 78 (39 × 2 tahun). Teknik analisis data pada penelitian ini menggunakan alat analisis uji paired sampel T-Test, karena penelitian ini dilakukan dengan membandingkan sampel penelitian penghindaran pajak sebelum dan saat Covid19. Penelitian ini menggunakan alat bantu IBM SPSS Statistic 24.

Penghindaran pajak pada penelitian ini menggunakan proksi Cash effective tax rate (CETR). Proksi ini menggambarkan rasio pajak yang dibayar oleh perusahaan per rupiah penghasilan yang diterima (Firmansyah \& Ardiansyah, 2020). Nilai Cash ETR dapat mengindikasikan adanya praktik penghindaran pajak, karena jika semakin rendah nilai Cash ETR maka semakin tinggi praktik penghindaran pajak yang dilakukan oleh perusahaan.

$$
\text { Cash ETR }=\frac{\text { Pajak Penghasilan yang dibayar }}{\text { Laba sebelum pajak }}
$$

\section{HASIL DAN PEMBAHASAN}

\section{Paired Sampel T-Test}

Pada penelitian ini menggunakan paired sampel T-Test, dimana pada uji ini digunakan karena merupakan bagian dari analisis statistic parametric. Uji paired sampel ini dilakukan untuk seluruh sampel sehingga hasilnya dapat digunakan untuk membandingkan praktik penghindaran pajak sebelum dan saat pandemi Covid-19. Berdasarkan uji paired sampel tersebut diperoleh hasil sebagai berikut:

Tabel 1. Hasil Uji Paired Samples Statistics

Paired Samples Statistics

\begin{tabular}{llr|r|r|r}
\hline & \multicolumn{1}{c}{ Mean } & N & \multicolumn{1}{c}{ Std. Deviation } & \multicolumn{1}{c}{ Std. Error Mean } \\
\hline \multirow{2}{*}{ Pair 1 } & SEBELUM & 23,97 & 39 & 12,750 & 2,042 \\
\cline { 2 - 6 } & SAAT & 17,87 & 39 & 7,442 & 1,192 \\
\hline
\end{tabular}

Berdasarkan hasil pengujian paired samples statistics pada sebelum pandemi Covid-19 memiliki nilai mean sebesar 23,97. Sedangkan untuk nilai mean saat pandemi sebesar 17,87 . Hal tersebut menunjukkan adanya penurunan nilai mean, sehingga secara deskriptif terdapat perbedaan tingkat penghindaran pajak pada sebelum dan saat pandemi Covid-19. Selanjutnya pada nilai standard deviation sebelum pandemi Covid-19 sebesar 12,750 dan saat pandemi Covid-19 sebesar 7,442. Yang artinya terjadi penurunan risiko perusahaan untuk melakukan praktik penghindaran pajak.

Tabel 2. Hasil Uji Paired Samples Correlations Paired Samples Correlations

\begin{tabular}{lrr|r|r}
\hline & & $\mathrm{N}$ & \multicolumn{1}{c|}{ Correlation } & \multicolumn{1}{c}{ Sig. } \\
\hline Pair 1 & SEBELUM \& SAAT & 39 &, 034 &, 838 \\
\hline
\end{tabular}

Hasil dari paired samples correlations diketahui nilai correlation sebesar 0,034 dengan nilai sig. sebesar 0,838 karena nilai sig. 0,838 > probabilitas 0,05 maka dapat dikatakan bahwa tidak ada hubungan antara variable sebelum pandemi Covid-19 dan variable saat pandemi
Covid-19. 
Tabel 3. Hasil Uji Paired Samples Test

Paired Samples Test

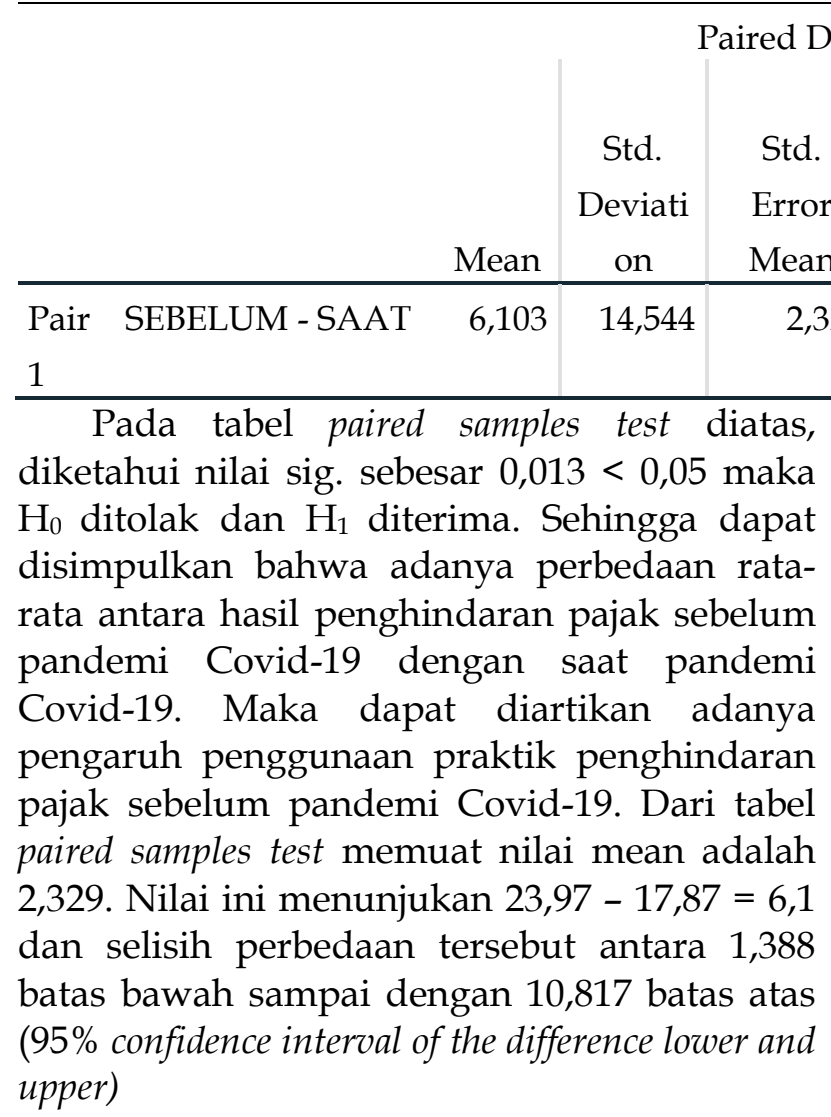

Berdasarkan tabel paired samples test diketahui thitung bernilai positif yaitu sebesar 2,620. T hitung bernilai positif ini disebabkan karena nilai rata-rata penghindaran pajak sebelum pandemi Covid-19 lebih tinggi dari pada penghindaran pajak saat pandemi Covid19. Dengan demikian, karena nilai $t$ hitung 2,620 > t tabel 2,023. Maka dapat disimpulkan bahwa $\mathrm{H}_{0}$ ditolak dan $\mathrm{H}_{1}$ diterima. Jadi ada perbedaan rata-rata antara penghindaran pajak sebelum pandemi Covid-19 dengan saat pandemi Covid-19 yang artinya terjadi praktik penghindaran pajak sebelum pandemi Covid19.

\section{Perbedaan tingkat praktik penghindaran pajak sebelum dan saat pandemi Covid-19}

Berdasarkan hasil hipotesis yang menyatakan H1 diterima, maka terdapat peningkatan praktik penghindaran pajak pada saat pandemi covid19. Hal ini dibuktikan dengan nilai CETR yang semakin rendah, maka semakin tinggi pula perusahaan melakukan praktik penghindaran pajak. Jika dikaitkan dengan teori agensi, pihak manajer berupaya untuk menstabilkan kondisi ekonomi perusahaan dengan cara meningkatkan laba karena pada masa pandemi banyak perusahaan yang mengalami penurunan penjualan. Sehingga perusahaan melakukan praktik penghindaran pajak untuk mengurangi besarnya beban pajak. Pemerintah memberikan upaya dengan cara memberikan insentif pajak kepada pelaku bisnis, nanum hal ini dianggap sebagai celah oleh perusahaan untuk melakukan praktik penghindaran pajak. hal ini sejalan dengan hasil penelitian yang dilakukan oleh suhaidar yang menyatakan bahwa terjadi peningkatan praktik penghindaran pajak pada saat pandemi covid 19. Namun berbeda dengan hasil penelitian yang dilakukan oleh firmansyah yang menyatakan bahwa tidak terdapat perbedaan tingkat penghindaran pajak sebelum pandemi dan saat pandemi.

\section{SIMPULAN}

Berdasarkan hasil penelitian diatas, maka dapat disimpulkan bahwa terjadi perbedaan praktik penghindaran pajak sebelum dan saat pandemi Covid-19. Dimana perbedaan tersebut mengakibatkan peningkatan praktik penghindaran pajak yang dilakukan oleh perusahaan pada saat pandemi Covid-19. Peningkatan ini dikarenakan adanya insentif pajak yang diberikan oleh pemerintah. Pemerintah berharap dengan adanya intensif pajak mampu meningkatkan produktivitas dan daya saing perusahaan. Seharusnya dengan adanya insentif pajak berguna bagi wajib pajak agar tetap menjalankan kewajiban untuk membayar pajak dengan baik tanpa harus mengambil tindakan penghindaran pajak agar tidak terjadi penurunan 
penerimaan pajak pada saat pandemi Covid19. Namun perusahaan menyalahgunakan intensif pajak tersebut sebagai celah untuk melakukan praktik penghindaran pajak. Faktor yang mendorong perusahaan melakukan praktik penghindaran pajak selain pemberian insentif pajak dari pemerintah yaitu dengan adanya dorongan dari pemegang saham kepada pihak manajer untuk mempertahankan kondisi ekonomi perusahaan. Pemerintah harus meningkatkan pengawasan terkait celah untuk melakukan praktik penghindaran pajak. Agar penerimaan Negara dapat mencapai target yang diharapkan. Penelitian ini tidak terjadi korelasi antara praktik penghindaran pajak sebelum dan saat pandemi Covid-19.

Keterbatasan dalam penelitian ini hanya membahas mengenai penghindaran pajak pada masa sebelum dan saat pandemi Covid19 dengan jangka waktu selama 2 tahun yaitu tahun 2019-2020. Selain itu, penelitian ini hanya menggunakan pengukuran proksi Cash ETR sehingga untuk penelitian selanjutnya disarankan untuk menggunakan proksi selain Cash ETR. Saran lain yang dapat digunakan oleh peneliti selanjutnya adalah dengan menambah jumlah variable yang mungkin berkaitan lebih besar terhadap penghindaran pajak. Serta menggunakan sektor selain perusahaan manufaktur.

\section{REFERENSI}

Adisamartha, \& Noviari. (2015). ISSN : 23031018 E-Jurnal Akuntansi Universitas Udayana Vol . 13 . 3 Desember ( 2015 ): 973-1000 WAJIB PAJAK BADAN Fakultas Ekonomi dan Bisnis Universitas Udayana Bali , Indonesia Fakultas Ekonomi dan Bisnis Universitas Udayana Bali , Indonesia Keywords: The Effect of Liquidity, Leverage, Inventory Intensity and Intensity of Fixed Assets on the Aggressiveness Level of Corporate Taxpayers, 13, 973-1000.

Anggraeni, T., \& Oktaviani, R. M. (2021). Dampak Thin Capitalization, Profitabilitas, Dan Ukuran Perusahaan Terhadap Tindakan Penghindaran Pajak.
Jurnal Akuntansi Dan Pajak, 21(02), 390397.

https:// doi.org/10.29040/jap.v21i02.1530

Asmara, C. G. (2020). Indonesia Resmi Resesi, Ini Buktinya "Perihnya" di Masyarakat. Retrieved from https://www.cnbcindonesia.com/news/ 20201107082302-4-200008/indonesiaresmi-resesi-ini-buktinya-perihnya-dimasyarakat

Chen, S., Xu, L., \& Jebran, K. (2021). The effect of Confucian culture on corporate tax avoidance: evidence from China. Economic Research-Ekonomska Istrazivanja , 34(1), 1342-1365.

https://doi.org/10.1080/1331677X.2020.1 825105

Firmansyah, A., \& Ardiansyah, R. (2020). Bagaimana Praktik Manajemen Laba Dan Penghindaran Pajak Sebelum Dan Setelah Pandemi Covid19 Di Indonesia?, 24(2), 32-51. Retrieved from www.idx.co.id.

Hanlon, M., \& Heitzman, S. (2010). A review of tax research. Journal of Accounting and Economics, 50(2-3), 127-178. https://doi.org/10.1016/j.jacceco.2010.09 .002

Irianto, D. B. S., \& S.Ak, A. W. (2017). The Influence of Profitability, Leverage, Firm Size and Capital Intensity Towards Tax Avoidance. International Journal of Accounting and Taxation, 5(2), 33-41. https://doi.org/10.15640/ijat.v5n2a3

Jensen, M. C., \& Meckling, W. H. (1976). Theory of The Firm: Managerial Behavior, Agency Cost and Ownership Structure. Journal of Financial Economics, 3, 305-360.

Kementrian Keuangan RI. (2020a). INSENTIF PAJAK UNTUK WAJIB PAJAK TERDAMPAK PANDEMI CORONA VIRUS DISEASE 2019. Retrieved from https://perpajakan.ddtc.co.id/peraturanpajak/read/peraturan-menterikeuangan-86pmk-032020

Kementrian Keuangan RI. (2020b). Pemerintah Berikan Insentif Pajak untuk Dukung DUnia Usaha dan Masyarakat Selama Pandemi COVID-19. Retrieved from https://www.kemenkeu.go.id/publikasi 
/ berita/pemerintah-berikan-insentifpajak-untuk-dukung-dunia-usaha-danmasyarakat-selama-pandemi-covid-19/

Khoirul Nisa, A., \& Wulandari, S. (2021). Pengaruh Tax Avoidance Dan Kepemilkan Institusional Terhadap Cost of Debt Pada Perusahaan Makanan Dan Minuman. Jurnal Aplikasi Akuntansi, 5(2), 201-219. https://doi.org/10.29303/jaa.v5i2.101

Laffitte, S., Martin, J., Parenti, M., Souilard, B., \& Farid, T. (2020). International Corporate Taxation after Covid-19: Minimum Taxation as the New Normal, (30), 6.

Marteleto, L. J., Guedes, G., Coutinho, R. Z., \& Weitzman, A. (2020). Live Births and Fertility Amid the Zika Epidemic in Brazil. Demography, 57(3), 843-872. https://doi.org/10.1007/s13524-02000871-x

Nidya, I. R. (2020). 5 Upaya Pemerintah Kembalikan Pertumbuhan Perekonomian Nasional. Retrieved from https://nasional.kompas.com/read/2020 /08/07/16224171/5-upaya-pemerintahkembalikan-pertumbuhanperekonomian-nasional

Nordiansyah, E. (2020). Lebih dari 451 Ribu Pengusaha Minta Insentif Pajak, Berapa yang Disetujui? Retrieved from https://www.medcom.id/ekonomi/mak ro/nbwlQwxk

Pattiasina, V., Tammubua, M. H., Numberi, A., Patiran, A., \& Temalagi, S. (2019). Capital Intensity and tax avoidance. International Journal of Social Sciences and Humanities, $3(1)$, 58-71. https://doi.org/10.29332/ijssh.v3n1.250 Septiawan, K., Ahmar, N., \& Darminto, D. P.
(2021). Detection of Tax Avoidance Due to the COVID-19 Pandemi with the Tax Aggressiveness Model. Proceedings of the 2nd International Conference on Business and Management of Technology (ICONBMT 2020), 175, 170-174. https://doi.org/10.2991/aebmr.k.210510. 029

Suhaidar, Rosalina, E., \& Pratiwi, A. (2020). FAKTOR-FAKTOR YANG MEMPENGARUHI PENGHINDARAN PAJAK DAMPAK SEBELUM DAN SELAMA COVID-19 PADA PERUSAHAAN MANUFAKTUR. Conference on Economic and Business Innovation, 19(11), 3-16.

Sunarto, S., Widjaja, B., \& Oktaviani, R. M. (2021). The Effect of Corporate Governance on Tax Avoidance: The Role of Profitability as a Mediating Variable. The Journal of Asian Finance, Economics and Business, $\quad$ 8(3), 217-227. https://doi.org/https://doi.org/10.1310 6/jafeb.2021.vol8.no3.0217

Temsah, M. H., Al-Sohime, F., Alamro, N., AlEyadhy, A., Al-Hasan, K., Jamal, A., ... Somily, A. M. (2020). The psychological impact of COVID-19 pandemi on health care workers in a MERS-CoV endemic country. Journal of Infection and Public Health, 13(6), 877-882. https://doi.org/10.1016/j.jiph.2020.05.02 1

Wildan, M. (2020). Indonesia Diperkirakan Rugi Rp69 Triliun Akibat Penghindaran Pajak. Retrieved from https://news.ddtc.co.id/indonesiadiperkirakan-rugi-rp69-triliun-akibatpenghindaran-pajak-25729? page_y $=554$ 